\title{
Effects of Extraction Conditions on the Componential Extraction of Brown Seaweed (Undaria pinnatifida)
}

\author{
Nan-Young Park', InSun Kim², and Yong-Jin Jeong ${ }^{3 \dagger}$ \\ ${ }^{1}$ Keimyung Foodex Co. Ltd., Daegu 702-701, Korea \\ ${ }^{2}$ Deptartment of Biology and ${ }^{3}$ Department of Food Science and Technology, \\ Keimyung University, Daegu 702-701, Korea
}

\begin{abstract}
In order to improve the market competitiveness of the processed products of Undaria pinnatifida, various extraction conditions of Undaria pinnatifida were examined to detemine the optimal conditions for the extraction of its valuable components. The highest level of alginic acid content was detected after 90 min of typical extraction or after $20 \mathrm{~min}$ of pressure extraction, after which the levels decreased slightly. The concentrations of reducing sugar and cnude protein were also high after $90 \mathrm{~min}$ of typical extraction. Both alginic acid and reducing sugar were extracted in greater amounts using pressure extraction. The reducing sugar content was $2.8 \sim 3.2$ times higher using pressure extraction rather than typical extraction. Furthemore, the extraction results were superior with the pressure extraction method. The appropriate temperature and duration of extraction were found to be $120^{\circ} \mathrm{C}$ for $20 \mathrm{~min}$. The use of a single enzyme yielded better results duning extraction compared to the use of a mixture of enzymes. $20 \mathrm{~min}$ of pressure extraction followed by the addition of $0.1 \%$ pectinase and 2 hr of further extraction at $50^{\circ} \mathrm{C}$ yielded high contents of alginic acid and reducing sugar from Undaria pinnatifida.
\end{abstract}

Key words: brown seaweed, Undaria pinnatifida, alginic acid, pectinase

\section{INTRODUCTION}

As an annual seaweed belonging to the brown algae family, the edible brown seaweed (Undaria pinnatifida) contains abundant amounts of sugar and minerals such as calcium, potassium, iron, and zinc, as well as vitamins and anti-carcinogenic substances. $40 \sim 80 \%$ of the sugars in brown algae is alginic acid, and it is also a major component of the cell wall $(1,2)$. Although alginic acid is indigestible by the human body, in the digestive system its functions include aiding the excretion of cholesterol, prevention of heavy metal (cadmium) and radioactive metal (strontium) absorption, and regulation of excretory processes (3). The alginic acid content in brown seaweed differs by seaweed type, harvest season, extraction methods (4), and seaweed part (5). The addition of enzymes such as cellulase, pectinase, and pentonase increase yields of alginic acid, and polysaccharide lytic enzymes increase yield in sea kelp extracts (6). Various studies have been conducted on alginic acid extraction methods and its molecular weight (7-9), mannuronic to glucuronic acid ratio (10), and differences in physical properties (11) depending on extraction methods. Brown seaweed is also reported to have a superior free radical scavenging effect (12). Brown seaweed is high in dietary fiber that cannot be broken down by the digestive enzymes of the body (7). Therefore, it is effective in diets preventing weight gain. In Korea, this seaweed has long been used to aid in the recovery of postpartum mothers as well as other ailing patients. Brown seaweed soup has traditionally been popular among Koreans because of its savory taste and appealing texture. Low in calories, brown seaweed offers many health and pharmacological benefits and thus can be used for many purposes. After initial processing, the seaweed is mostly distributed in a dried or salted form. Unfortunately, productivity in the brown seaweed industry is declining due to decreasing domestic consumption and increased export to Japan.

To increase its consumption, brown seaweed has been processed into laver $(13,14)$, Kimchi (15), cookies (16), and tea (17). However, consumer interest is still lagging. Thus, this study investigates effective ways to extract the conditions of brown seaweed in order to increase the market competitiveness of its processed products.

\section{MATERIALS AND METHODS}

\section{Materials}

The brown seaweed (Undaria pinnatifida) used in this study was obtained from Jungwol Susan (Gampo, Korea) 
as frozen samples. Once they were thawed, the samples were immersed in water for $2 \mathrm{hr}$ to desalt and hydrate, and then ground twice in a food grinder $(\mathrm{MH}$, Hanil Co., Korea).

\section{Nomal and pressure extraction}

After grinding $50 \mathrm{~g}$ of raw brown seaweed, water was added until the water content reached $200 \%(\mathrm{w} / \mathrm{w})$. This material was then treated at $100^{\circ} \mathrm{C}$ for $30 \sim 150 \mathrm{~min}$ for typical extraction and at $120^{\circ} \mathrm{C}$ for $10 \sim 60$ min for pressure extraction.

Extraction according to enzyme type, concentration, and time

Different concentrations $(0.05 \%, 0.1 \%$, and $0.2 \%$ $(w / v))$ of the enzymes cellulase (Daiwa, Sumizyme, 30,000 unit, Japan) or pectinase (Rapidase MAXC 80, Kyowa Co., 80,000 unit, Japan) were added to the raw brown seaweed extract and rotated at $50^{\circ} \mathrm{C}$ for alternating time periods of $2 \mathrm{hr}$ or $4 \mathrm{hr}$.

\section{Yield, turbidity, and $\mathbf{p H}$}

The yield from the raw brown seaweed extract was obtained by calculating the residual quantity after centrifugation at 10,000 rpm for $15 \mathrm{~min}$. Turbidity was calculated by measuring absorbance at $660 \mathrm{~nm}$. After centrifuging the solution at $10,000 \mathrm{rpm}$ for $15 \mathrm{~min}$, a $\mathrm{pH}$ meter (Metrohm 691, Swiss) was used to measure the $\mathrm{pH}$ of the supernatant from the brown seaweed extraction solution.

\section{Alginic acid content}

Alginic acid was obtained as calcium alginate by adding a $\mathrm{CaCl}_{2}$ solution to the brown seaweed extract. Diluted hydrochloric acid was added to the calcium alginate to remove excess calcium, and the mixture was then centrifuged to dehydrate. Methyl alcohol containing $\mathrm{NaOH}$ was added to the precipitate. The test tube was closed off, rotated, and centrifuged to dehydrate the mixture and convert the precipitate into sodium alginate. The sodium alginate in methyl alcohol was compressed to remove the alcohol. The sample was dried under hot air, and the dried sample was weighed to calculate the alginic acid content per $100 \mathrm{~mL}$ of extraction solution (18).

\section{Reducing sugar content}

A mixture of $1 \mathrm{~mL}$ of brown seaweed extract and 1 $\mathrm{mL}$ of DNS (Dinitrosalicylic acid) solution was heated in a water bath for $10 \mathrm{~min}$ and cooled quickly thereafter. $3 \mathrm{~mL}$ of distilled water was then added and a UV-spectrophotometer (Shimadzu UV-1601PC, Japan) was used at $546 \mathrm{~nm}$ to read the absorbance of the mixture. A standard curve was then generated using glucose as the standard and the amount of reducing sugar was quantified.

\section{Crude protein content}

Using the Lowry method (19) and a UV-spectrophotometer (Shimadzu UV-1601PC, Japan) at $750 \mathrm{~nm}$ crude protein was assayed after color was developed by reacting the alkaline $\mathrm{CuSO}_{4} \cdot 5 \mathrm{H}_{2} \mathrm{O}$ reagent with $1 \mathrm{~mL}$ of the brown seaweed extract.

\section{Statistical analyses}

The experiment was repeated 3 times, and the results were expressed in terms of the mean $\pm \mathrm{SD}$. However, the free amino acid content was measured only once.

\section{RESULTS AND DISCUSSION}

Changes in alginic acid and cnude protein content

Using typical extraction, the alginic acid content in the brown seaweed extract increased slightly with extraction time. By 90 min of extraction, it reached its highest level and then decreased slightly afterwards. With the pressure extraction method the alginic acid content reached its highest level by 20 min of extraction and decreased afterwards as extraction time increased (Fig. 1). The amount of alginic acid extracted was higher with pressure extraction than with typical extraction. In the case of Laminaria japonica, the alginic acid content has been shown to be $0.26 \sim 1.05(\mathrm{~g} / 100 \mathrm{~mL})$, which is similar to that found in the brown seaweed (20); however, the brown seaweed exhibited a particular pattern of dramatic increase in alginic acid level in the first 2 hr of extraction followed by a slower increase thereafter. Unlike the results of this study, Kim and Choi (20) reported that the alginic acid content in brown seaweed is highest at the $2 \mathrm{hr}$-time point of extraction. The crude protein content increased with extraction time under typical extraction, reaching its maximum value by the 90 min-time point and then decreasing afterwards. In contrast, with pressure extraction the crude protein content increased with extraction time, decreased slightly by 50 min of extraction, and then increased again thereafter. As was the case with alginic acid content, the crude protein content was higher with pressure extraction than with typical extraction (Fig. 1).

\section{Changes in yield, turbidity, $\mathrm{pH}$, and reducing sugar content}

With typical extraction, the reducing sugar yield did not change significantly between $30 \sim 90 \mathrm{~min}$ of extraction, but did increase noticeably by $120 \mathrm{~min}$, with no significant change afterwards (Table 1). This resulting yield was significantly higher than the $44 \sim 59 \%$ yield which has been reported by Kim and Choi (20), whose 

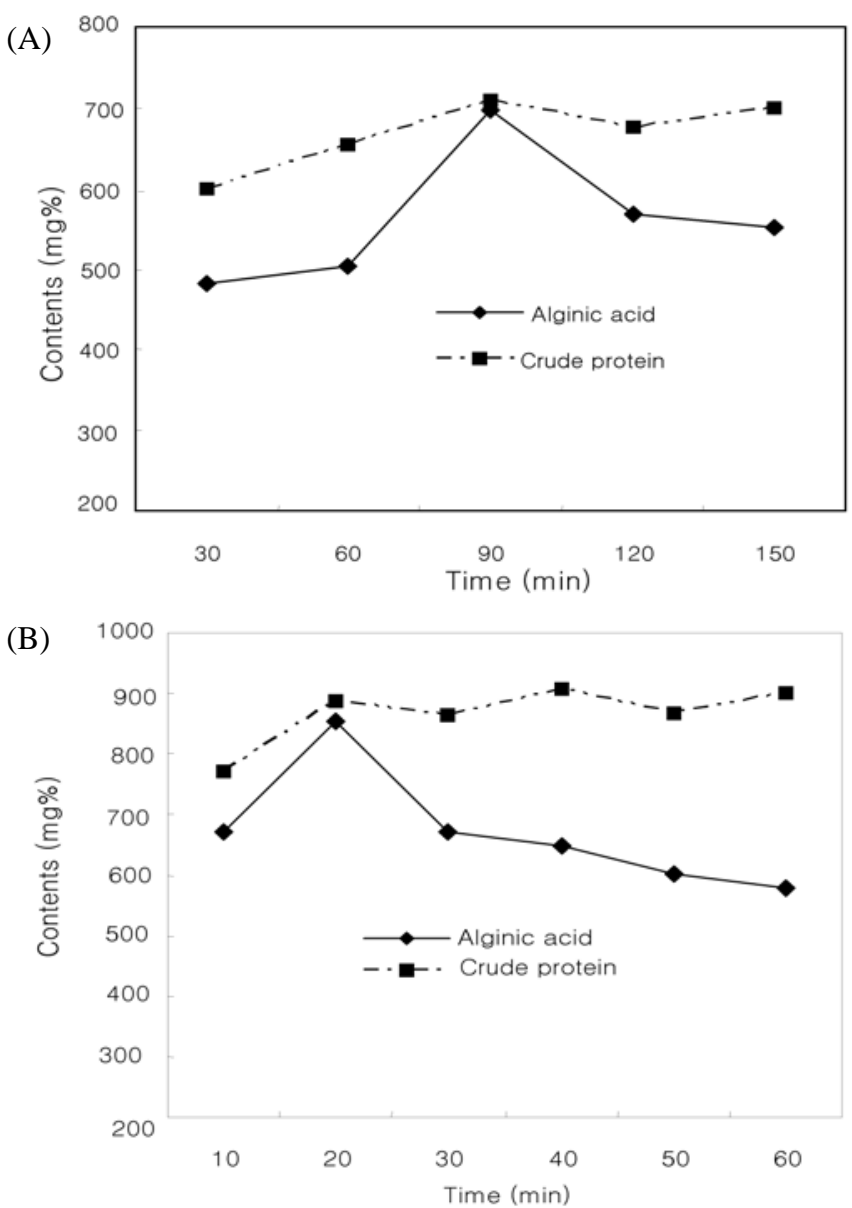

Fig. 1. Changes in the alginic acid and crude protein content of brown seaweed under different extraction times using typical (A) and pressure (B) extraction.

methods included heat-treating the brown seaweed after the addition of enzyme, acid, and $\mathrm{Na}_{2}$ EDTA. The temperature set for pressure extraction was $120^{\circ} \mathrm{C}$, de- termined appropriate from preliminary testing. The yield increased as the extraction time increased for pressure extraction; however, the time required for optimal extraction was significantly shorter for pressure extraction than for typical extraction. With typical extraction the extraction time did not appear to significantly affect the results. Additionally, the temperature had an apparent effect on the results of the extraction (21) (Table 2). With typical extraction turbidity decreased as extraction time increased, similar to the results found in the brown seaweed extraction experiments performed by Kim and Choi (20). Similarly, turbidity decreased as extraction time increased using pressure extraction. The $\mathrm{pH}$ appeared to affect the alginic acid solution; hydrolysis of $\mathrm{H}^{+}$ions occurred under $\mathrm{pH}$ conditions lower than $\mathrm{pH}$ 5 , lowering the viscosity significantly (22). In this study, the $\mathrm{pH}$, which ranged from $6.34 \sim 6.49$, did not seem to be greatly influenced by extraction time, nor did it have an effect on alginic acid. With pressure extraction, changes in $\mathrm{pH}$ were not significantly affected by extraction time either. Thus, results concerning changes in turbidity and $\mathrm{pH}$ were similar to those found when using the typical extraction method. For brown seaweed extracts derived from typical extraction, the content of reducing sugar typically increase with extraction time (23). With pressure extraction, the reducing sugar content also increased with extraction time although at levels 2.8 3.2 times higher than with typical extraction. The cause of this is likely the dissociation of polysaccharides present in the brown seaweed which become reducing sugars under the added pressure from pressure extraction. Therefore, pressure extraction appears to be more effective than typical extraction in extracting brown seaweed

Table 1. Changes in the yield, turbidity, $\mathrm{pH}$, and reducing sugar content of brown seaweed under different extraction time

\begin{tabular}{lrrrrr}
\hline & \multicolumn{5}{c}{ Time (min) } \\
\cline { 2 - 6 } & \multicolumn{1}{c}{30} & \multicolumn{1}{c}{60} & \multicolumn{1}{c}{120} & \multicolumn{1}{c}{150} \\
\hline Yield (\%) & $63.11 \pm 0.60^{1)}$ & $62.19 \pm 0.38$ & $62.89 \pm 0.07$ & $67.8 \pm 0.16$ & $67.56 \pm 0.46$ \\
Turbidity (660 nm) & $0.237 \pm 0.00$ & $0.115 \pm 0.00$ & $0.153 \pm 0.01$ & $0.084 \pm 0.00$ & $0.082 \pm 0.00$ \\
pH & $6.49 \pm 0.04$ & $6.45 \pm 0.00$ & $6.41 \pm 0.01$ & $6.42 \pm 0.04$ & $6.34 \pm 0.01$ \\
Reducing sugar (mg\%) & $17.41 \pm 0.34$ & $21.33 \pm 0.35$ & $25.25 \pm 0.95$ & $31.49 \pm 0.64$ & $33.22 \pm 0.72$ \\
\hline
\end{tabular}

${ }^{1)}$ Mean \pm SD of triplicate determinations.

Table 2. Changes in the yield, turbidity, $\mathrm{pH}$, and reducing sugar content of brown seaweed under different extraction times using pressure extraction

\begin{tabular}{lcrrrrr}
\hline & \multicolumn{6}{c}{ Time (min) } \\
\cline { 2 - 7 } & \multicolumn{1}{c}{10} & \multicolumn{1}{c}{20} & \multicolumn{1}{c}{40} & \multicolumn{1}{c}{50} & 60 \\
\hline Yield (\%) & $67.18 \pm 0.35^{1)}$ & $70.89 \pm 0.34$ & $73.05 \pm 0.44$ & $77.25 \pm 0.22$ & $80.00 \pm 0.32$ & $82.62 \pm 0.47$ \\
Turbidity (660 nm) & $0.123 \pm 0.01$ & $0.076 \pm 0.00$ & $0.052 \pm 0.00$ & $0.043 \pm 0.00$ & $0.040 \pm 0.00$ & $0.042 \pm 0.00$ \\
pH & $6.38 \pm 0.04$ & $6.34 \pm 0.02$ & $6.32 \pm 0.01$ & $6.26 \pm 0.01$ & $6.24 \pm 0.00$ & $6.23 \pm 0.01$ \\
Reducing sugar (mg\%) & $32.72 \pm 0.90$ & $42.85 \pm 1.07$ & $48.50 \pm 1.56$ & $57.17 \pm 0.87$ & $63.02 \pm 0.41$ & $67.55 \pm 0.76$ \\
\hline
\end{tabular}

\footnotetext{
${ }^{1)}$ Mean \pm SD of triplicate determinations.
} 
components and generating a high extraction yields.

\section{Effects of enzyme treatments}

The pressure extraction was carried out for 20 min at $120^{\circ} \mathrm{C}$, after which pectinase and cellulase were added at varying concentrations $(0.05 \sim 0.2 \%)$ and the extraction continued for $2 \mathrm{hr}$ at $50^{\circ} \mathrm{C}$. After pressure extraction and enzyme treatment, the yield derived from the brown seaweed extract was $17 \%$ higher than that obtained from typical extraction only. When compared to pressure extraction alone, up to $40 \mathrm{~min}$ of pressure extraction followed by enzyme treatment resulted in a slightly higher yield; however, this value was still lower than the resulting yield from subjecting the brown seaweed to 50 60 min of pressure extraction alone (Fig. 2). The content of reducing sugar, which comprises most of the sugar in the brown seaweed extract, was 3.0 5.8 times higher with pressure extraction followed by enzyme treatment than with typical extraction alone, and 1.5 3.0 times higher than with pressure extraction alone. The reducing sugar content was likely high due to the effective disintegration of sugars present in the
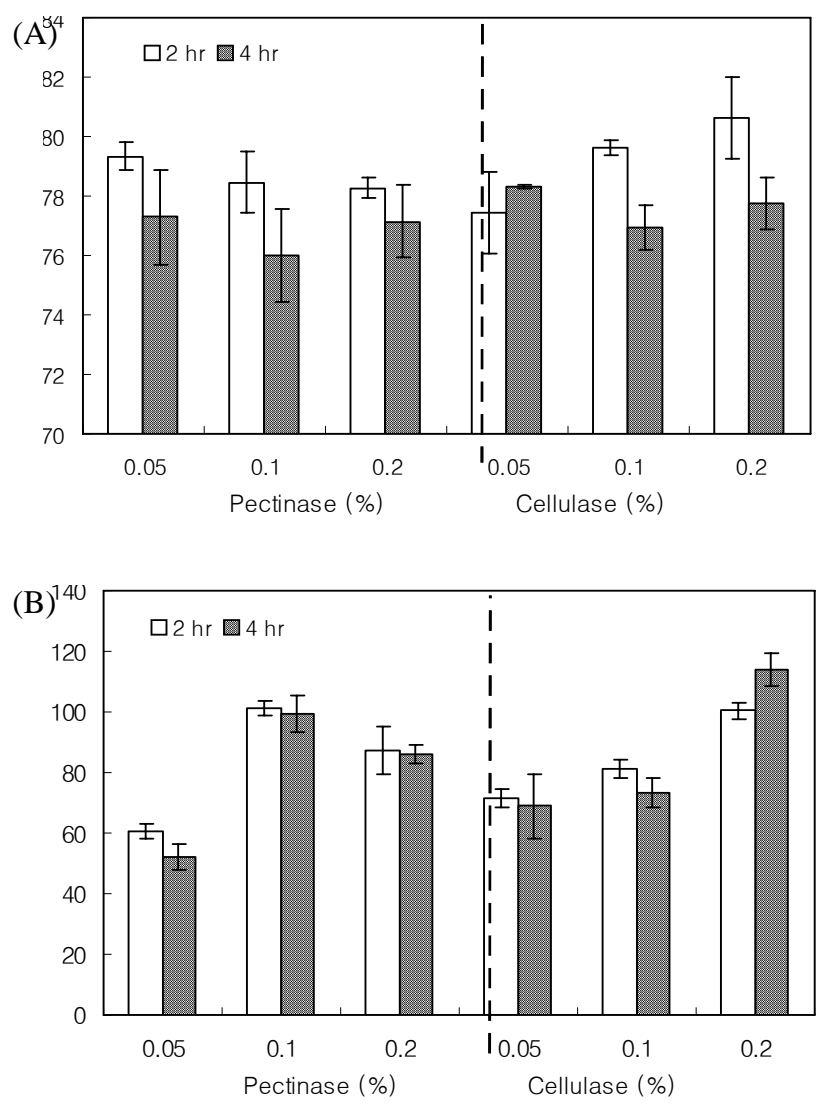

Fig. 2. Changes in the yield (A) and reducing sugar content (B) of brown seaweed after extraction with different types of enzymes at varying concentrations. Mean $\pm \mathrm{SD}$ of triplicate determinations. brown seaweed as a result of enzyme treatment. At a slightly lower $\mathrm{pH}$ of $6.04 \sim 6.07$, the difference in $\mathrm{pH}$ after pressure extraction followed by enzyme treatment was not significantly different compared to when the two extraction methods were each performed alone. However the turbidity value after pressure extraction and enzyme treatment, ranging between $0.040 \sim 0.055$, was notably lower than when either the normal or pressure extractions were performed alone. This finding suggests that the enzyme treatment following the pressure extraction decreased the turbidity of the extract (Fig. 3). The crude protein content in the brown seaweed extract measured after pressure extraction with enzyme treatment was similar to that obtained during normal and pressure extractions without the use of enzymes (Fig. 4). A likely explanation for this is that the different enzymes used in this study targeted sugars only and thus the protein content in the extract was unaffected. The alginic acid content in the pressure-extracted, enzyme-treated brown seaweed extract was $1.6 \sim 2.0$ times higher than when typical extraction was performed alone, and only slightly
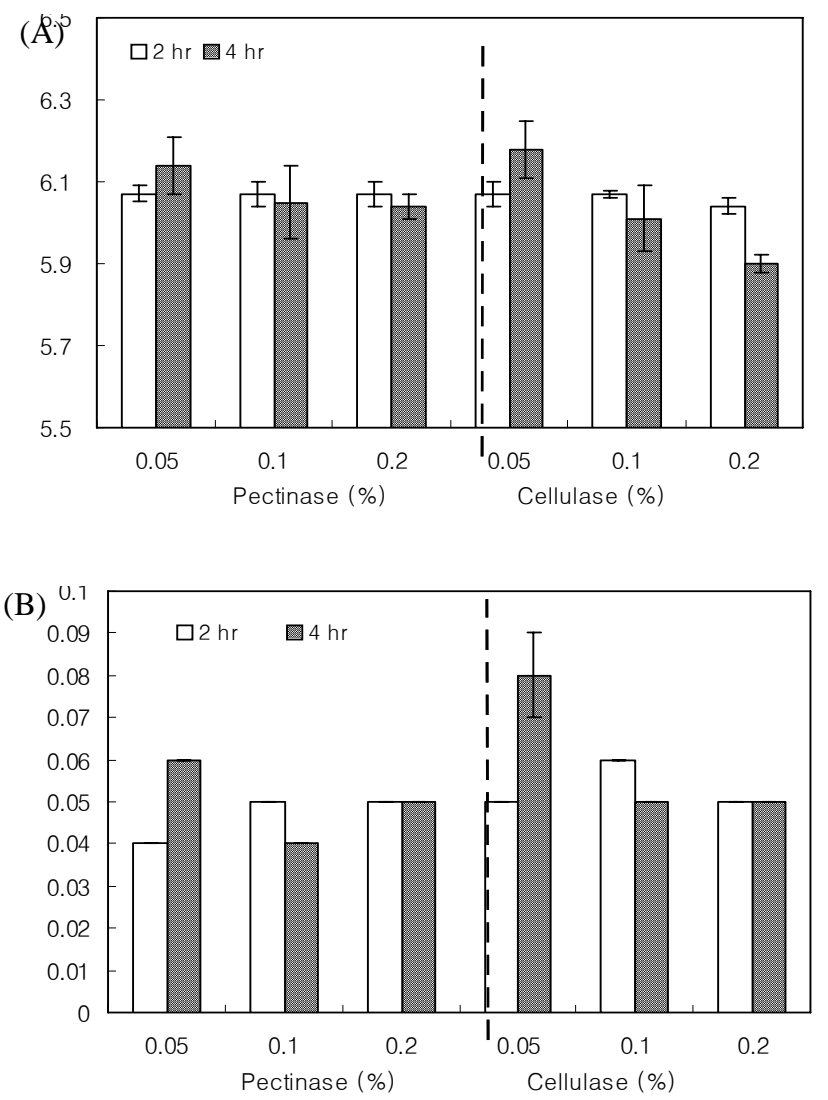

Fig. 3. Changes in the $\mathrm{pH}$ (A) and turbidity (B) of brown seaweed after extraction with different types of enzymes at varying concentrations. Mean $\pm \mathrm{SD}$ of triplicate determinations. 


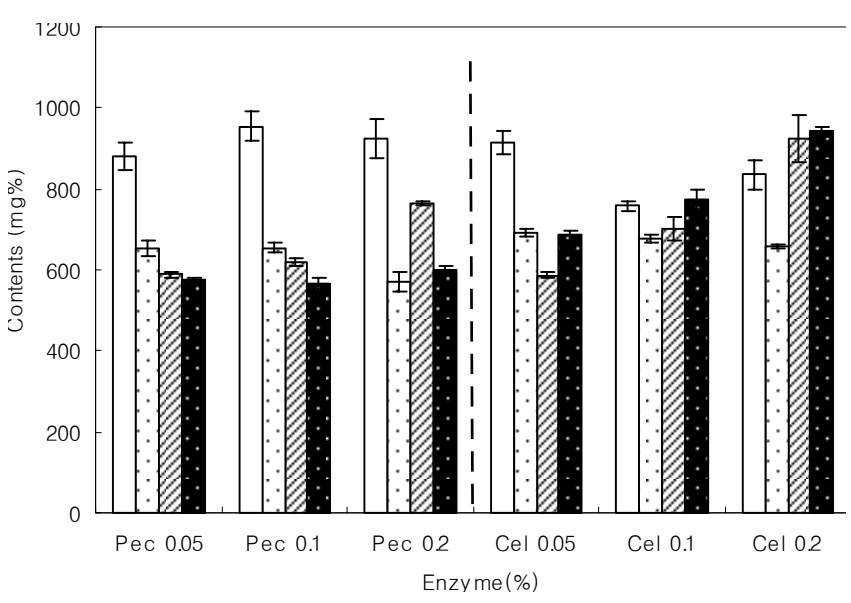

Fig. 4. Changes in the alginic acid and crude protein content of brown seaweed after extraction with different types of enzymes at varying concentrations. Pec, pectinase; Cel, cellulose. Mean \pm SD of triplicate determinations. $\square$, alginic acid (2 hr); , alginic acid (4 hr); $₫$, crude protein (2 hr); (4 hr).

higher than when pressure extraction was performed alone. Collectively these results suggest that enzyme treatment following pressure extraction is a more effective means of extracting valuable substances from brown seaweed than normal or pressure extraction alone.

\section{Effects of extraction time}

Fig. 2 4 show changes in the brown seaweed based on the duration of enzyme treatment following pressure extraction. The yield after $2 \mathrm{hr}$ of enzyme-treated extraction was slightly higher than that after $4 \mathrm{hr}$ regardless of enzyme type. The $\mathrm{pH}$ and turbidity were slightly higher with $4 \mathrm{hr}$ of $0.5 \%$ pectinase and $0.5 \%$ cellulase treated extraction but in most other cases exhibited similar trends (Fig. 2). With cellulase treatment, the change in crude protein content was slightly larger after $4 \mathrm{hr}$ of extraction compared to results from the $2 \mathrm{hr}$ interval. With pectinase however, the crude protein content actually decreased with $4 \mathrm{hr}$ of extraction compared to 2 $\mathrm{hr}$, and no significant changes were detectable as enzyme concentrations were increased (Fig. 4). The alginic acid content displayed a decreasing trend when results from $4 \mathrm{hr}$ of enzyme-treated pressure extraction were compared to those of $2 \mathrm{hr}$ of identical treatment. This trend was true regardless of enzyme type and concentration. A probable explanation for this is that as the enzyme treatment times were increased, the molecular weight of alginic acid decreased as it was being broken down into monosaccharide.

\section{Effects of enzyme type and concentration}

Among the changes observed in the brown seaweed extract after treatment with different enzymes at varying concentrations, the yield was highest for pectinase when used at a $0.05 \%$ concentration. No considerable differences were noted among the other concentrations. For cellulase, the yield increased as enzyme concentration increased (Fig. 2). The yields resulting from cellulase treatment did not differ significantly based on enzyme type but were noted to be highest at a concentration of $0.2 \%$. These findings differ somewhat from the results reported in a previous study suggesting that the addition of enzymes increased solid content concentration and yield (24). The alginic acid content was highest when the extract was treated with $0.1 \%$ pectinase. Overall, the alginic acid content was higher with pectinase than with cellulase. No differences were seen in turbidity or $\mathrm{pH}$ according to enzyme type and concentration; however, crude protein content increased as enzyme concentration increased. The value for the highest resulting crude protein content was significantly higher than the $0.13 \%$ protein content reported by Choi et al. (25). The reducing sugar content was highest with $0.1 \%$ pectinase or $0.2 \%$ cellulase treatment. The sugar content increased with an increased concentration of cellulase but not pectinase. The optimal enzyme concentration for extraction is thus determined to be $0.1 \%$ pectinase. Kim and Choi (20) reported similar results with a $0.1 \%$ enzyme treatment, supporting a finding of this study - reducing sugar content decreases due to the dissociation of alginic acid as enzyme concentrations are increased.

Changes in extraction according to mixed enzymes After being subjected to pressure extraction for $20 \mathrm{~min}$ the brown seaweed was treated with an enzyme mixture of varying pectinase to cellulase ratios of either $3: 1$ or 1:3 (Table 3). The different enzyme ratios did not significantly affect the yield, and furthermore the yield was not much different from when a single enzyme was used. This finding differs from the results reported by Kim and Choi (20). According to Kim and Choi (20), the yield was highest when the enzyme mixture ratio was 1:1. The contents of alginic acid and crude protein were similar or in some cases decreased with mixed enzyme

Table 3. Changes in the yield, alginic acid content, reducing sugar content, $\mathrm{pH}$, turbidity, and crude protein content of brown seaweed after mixed enzyme extraction

\begin{tabular}{lrr}
\hline Mixing ratio & \multicolumn{1}{c}{$3: 1^{1)}$} & \multicolumn{1}{c}{$1: 3$} \\
\hline Yield (\%) & $78.04 \pm 0.13^{2)}$ & $77.46 \pm 0.23$ \\
Alginic acid (mg/100 mL) & $641.00 \pm 10.0$ & $679.00 \pm 10.0$ \\
Reducing sugar (mg\%) & $43.69 \pm 2.47$ & $41.23 \pm 0.84$ \\
pH & $6.32 \pm 0.07$ & $6.28 \pm 0.04$ \\
Turbidity (660 nm) & $0.08 \pm 0.00$ & $0.08 \pm 0.00$ \\
Crude protein (mg\%) & $689.01 \pm 22.47$ & $798.27 \pm 1.98$ \\
\hline
\end{tabular}

\footnotetext{
${ }^{1)}$ Mixing enzyme: pectinase + cellulose.

${ }^{2)}$ Mean \pm SD of triplicate determinations.
} 
treatment, and $\mathrm{pH}$ values were slightly higher when treated with an enzyme mixture as opposed to a single enzyme. The content of reducing sugar was markedly lower with mixed enzyme treatment compared to single enzyme treatment. This result was similar to that obtained from 30 min of pressure treatment, and slightly higher than that obtained from typical extraction. The results from a mixed enzyme extraction were not better than those from a single enzyme extraction. In conclusion, the best results were obtained when the brown seaweed was subjected to 20 min of pressure extraction, treated with $0.1 \%$ pectinase, and further extracted for 2 hr at $50^{\circ} \mathrm{C}$.

\section{REFERENCES}

1. Haug A, Larson B, Smidsrod O. 1966. A study of the constitution of alginic acid by partial acid hydrolysis. Acta Chem Scand 20: 183-190.

2. Hirst EL, Percival E, Wold JK. 1964. The structure of alginic acid. Part Partial hydrolysis of the reduced polysaccharide. J Chem Soc 8: 1493-1499.

3. Ito K, Tsuchiya Y. 1972. The effect of algal polysaccharides on the depressing of plasma cholesterol levels in rat. In Proc. of 7th Int Seaweed Symp. Nishizawa K, ed. Univ. Tokyo Press, Tokyo, Japan. p 558-561.

4. Park YH. 1969. Seasonal variation in the chemical composition of brown algae with special reference to alginic acid. $J$ Korean Fish Soc 2: 71-82.

5. Kim CY, Park YH. 1975. Alginic acid contents in brown alga. Bull Natl Fish Univ (Busan) 15: 27-30.

6. Martin G. 1982. Food hydrocolloids. CRC Press, NY, USA. p 219-228.

7. Nishide E, Kinoshita Y, Anzai H, Uchida N. 1988. Distribution of hot-water extractable material, water-soluble alginate and alkali-soluble alginate in different parts of brown seaweed. Nippon Suisan Gakkaishi 54: 16191622.

8. Nishide E, Anzai H, Uchida NA. 1987. Comparative investigation on the water-soluble and the alkali-soluble alginates from various Japanese brown algae. Nippon Suisan Gakkaishi 53: 1215-1219.

9. Fujihara M, Nagumo T. 1989. Determination of the molecular weight of alginates by agrose gel filtration. $J$ Chromatogr 465: 386-389.

10. Noda K, Takada K. 1983. Mannuronic to guluronic acid rations of alginic acid prepared from various brown seaweeds. Bull Jpn Soc Fish 49: 1591-1593.

11. Cho SY, Kang HJ, Joo DS, Lee JS, Kim SM. 1999. A comparative study on physical properties and gel formation abilities of hot-water extractable material, watersoluble alginate and alkali-soluble alginate extracted from Laminaria japonica in East Sea, Korea. J Korean Fish Soc 32: 774-778.

12. Han J, Kang S, Choue R, Kim H, Leem K, Chung S, Kim C, Chung J. 2002. Free radical scavenging effect of Diospyros kaki, Laminaria japonica and Undaria pinntifida. Fitoterapia 73: 710-712.

13. Kim KH, Kim CS. 1982. Studies on the manufacture of Undaria pinntifida Laver and it's physicochemical properties. Korean J Food Sci Technol 14: 336-341.

14. Kim KH, Kim CS. 1983. Studies on the manufacture of Undaria pinntifida Laver and its physicochemical properties (II). Korean J Food Sci Technol 15: 277-281.

15. Kim YD, Kim YM, Kang TS. 1981. Study on versatile utilization of seaweeds. Korea advanced food research institute research report. p 86-88.

16. Seo KB, Choi DY, Yoon SH. 1975. Processing experiment using seaweeds. Korea advanced food research institute research report. p 105

17. Jo KS, Do JR, Koo JG. 1998. Pretreatment conditions of Porphyra yezoensis, Undaria pinnatifida and Laminaria religiosa for functional algae-tea. J Korean Soc Food Sci Nutr 27: 275-280.

18. Jung JY, Hur SS, Choi YH. 1999. Studies on the efficient extraction process of alginic acid in sea tangle. Food Engineering Progress 3: 90-97.

19. Lowry OH, Rosebrough NJ, Farr AL, Randall RJ. 1951. Protein measurement with the folin phenol reagent. $J$ Biol Chem 193: 265-269.

20. Kim WJ, Choi HS. 1994. Development of combined methods for effective extraction of sea mustard. Korean J Food Sci Technol 26: 44-50.

21. Lee GD, Kim JO, Joo GJ, Kwon JH. 2005. Optimum conditions for the extraction of effective substances from the stem of Opuntia fiscus-indica. Food Sci Biotechnol 14: 190-195.

22. Kim KH, Cheong JJ. 1984. Optimum conditions for extracting alginic acid from Undaria pinnatifida and amino acid composition of its extraction residue. Korean J Food Sci Technol 16: 336-340.

23. Jeong YJ. 2004. Optimization of extraction conditions on physicochemical properties of extracts from stem barks of Kalopanax pictus. Food Sci Biotechnol 13: 733-738.

24. Choi HS, Kim WJ. 1993. Effects of polysaccharide hydrolase on solids yields and viscosity of aqueous extracts of sea mustard. Korean J Food Sci Technol 25: 589-591.

25. Choi HS, Kim JG, Kim WJ. 1992. Effects of $\mathrm{HCl}$, sugar, salt and sequestrants on some quality properties of aquaeous extracts of sea mustard. Korean J Food Sci Technol 24: 387-392.

(Received September 3, 2008; Accepted November 14, 2008) 